\title{
The Verbal Paradigm in Embedded Clauses
}

In this chapter, a selection of substantival, adjectival, and adverbial clauses is discussed. The discussion is centered on the functional oppositions marked by the verbal forms in these clauses. Each section starts with the analysis of the simple and modified forms, then the compound and the negated forms are discussed. Limited distribution or special uses of a form are specifically noted. Given that some observations are relevant for more than one type of clauses - sometimes even for all - a certain amount of repetition is inevitable. Some semantic notions and other relevant concepts are mentioned only in brief, awaiting further elaboration in the following chapters.

\subsection{Preliminaries}

In the hierarchical structure of the text, embedded clauses constitute the lowest stratum. Embedded clauses are constituents of complex clauses: they occupy the syntactic position of a noun-phrase or an adverbial. In most cases, they do not refer directly to the deictic center of the text (see above 4.2), but relate to it via their matrix clause (for an exception, see [7.72] below). Since embedded clauses do not refer directly to the situation of the speaking/narrating subject, the expression of certain modal meanings, in particular volition, is less salient in them. In general, indicators of subjective involvement are more limited in embedded clauses, though not entirely absent from them. Embedded generic clauses, like all generic clauses, have a privative referential value. However, within the generic domain, one verbal situation may refer to another, thus being assigned a location in time which is relative to it.

The verbal paradigm in embedded clauses consists of indicative forms: simple, modified, and compound. With simple forms, the non-symmetrical configuration of [main clause + embedded clause] is syntactically marked, by the embedding operator and the syntagmatic sequence; with modified and compound forms, it is also morphologically marked, by the modifier or the auxiliary (against the use of a simple form in the main clause).

An important feature which affects the interpretation of the verbal form is the nature of the verbal lexeme or verb-phrase. There are two pertinent semantic distinctions in this regard: the first, between potentially bounded (telic) and unbounded (a-telic) situations, and the second, between situations

(C) MICHAL MARMORSTEIN, 2016 | DOI: 10.1163/9789004310483_008

This is an open access chapter distributed under the terms of the Creative Commons

Attribution-Noncommercial-Non-Derivative 3.o Unported (CC-BY-NC-ND) License

Michal Marmorstein - 9789004310483 
analyzable into phases, i.e. (dynamic) activities, and ones which are not, i.e. (static) states. ${ }^{1}$

The verbal forms may be sorted into two groups: the first comprises the simple forms yaf'alu, fa'ala, and the active participle, which do not mark the verbal situation as necessarily bounded; the second group comprises the modified forms sa-yaf'alu, qad fa'ala, and the passive participle, which impose an initial or terminal bounding of the verbal situation.

\subsection{Substantival (Content) 'anna-clauses}

The operator 'anna introduces content clauses of verbs of knowledge and acquisition of knowledge (including perception). Rarely, they also follow desiderative verbs. Clauses introduced by 'anna may function as object complements of verbs or as genitive complements of prepositions, e.g.: li-'anna, ka-'anna, ma' 'anna. The operator 'anna heads a nominal clause whose nominal theme is assigned the accusative case.

Given their high frequency in the corpus, substantival 'anna-clauses provide a good starting point for the exploration of the verbal paradigm in embedded clauses. The observations made henceforth regarding the semantic oppositions marked by the verbal forms are for the most part also pertinent in adjectival and adverbial clauses.

The contour of a verbal situation, including its temporal value, is largely determined by the interaction between the verbal lexeme and the verbal form, or to be more precise, between the internal and the external boundary-marking of the verbal situation. Modal nuances are more context dependent than aspectual and temporal meanings, thus not as easily predictable. The time reference of the verbal form is relative to the one established in the main clause. We observe that:

- Both yaf'alu and $f \bar{a}^{c} i l V n$ indicate concurrence with unbounded (including stative) lexemes and posteriority with bounded ones. ${ }^{2}$ The difference is that

1 Though correlating to a large extent, the distinction between these two sets of semantic oppositions should be kept, as the verbal forms interact differently with each of them. Cf. Rothstein, Structuring Events, 12 ff., for a classification of events according to the 'two aspectual properties' defined as [ \pm stage] and [ \pm telic].

2 I use the term 'concurrence' to refer to the temporal relation between two (or more) events which co-occur at the same time frame, though not necessarily at the very same instant. I use the term 'simultaneity' to refer to exact synchronicity. 
yaf'alu marks the dynamic unfolding of the situation while $f \bar{c} i l V n$ marks it as static. Futurity expressed by yaf'alu nearly always involves a modal flavor, whereas with $f \bar{c} i l V n$, a modal meaning does not surface as much. ${ }^{3}$

- sa-yaf'alu indicates that the situation is yet to occur and thus has a posterior time reference with all lexemes, regardless of their being bounded or unbounded, dynamic or static.

- fa'ala indicates persistence ('existing state') with stative lexemes and anteriority with dynamic, either bounded or unbounded, lexemes. ${ }^{4}$

- Both qad fáala and maf'ülVn indicate a bounded verbal situation. The difference is that qad facala depicts a state resulting from a previous process, thus it is analyzable into phases, ${ }^{5}$ while $m a f^{\prime} \bar{u} l V n$ refers to the resultant state alone.

Table 7.1 summarizes the aspectual and temporal distinctions marked by the verbal forms in 'anna-clauses. The examples which follow illustrate each case referred to in the table. Notice that with sa-yaf'alu, maf'ülVn and qad fa'ala only examples with potentially unbounded lexemes are adduced, to show the bounding force of the verbal form:

\section{TABLE 7.1 Temporal-aspectual distinctions in 'anna-clauses}

Time reference

Verbal form

Bounded lexeme Unbounded lexeme

\begin{tabular}{l|l|l}
\hline yaf'alu & posteriority [7.1] & concurrence-dynamic [7.2] \\
\hline$f a ̈ c i l V n$ & posteriority [7.3] & concurrence-static [7.4] \\
\hline sa-yaf'alu & \multicolumn{2}{|c}{ posteriority [7.5] } \\
\hline
\end{tabular}

3 For a more detailed discussion of futurity as expressed by yaf'alu, see below 9.2.1.

4 The meaning paraphrased as 'present state exists' emerges from the interaction of 'anteriors' and stative predicates; see Bybee, Perkins, and Pagliuca, Evolution, 74.

5 I hold a different view than Beeston, Arabic Language, 78, who ascribes to qad a 'conversive force', by which the dynamic aspect of the 'suffix-set' is transformed into a static one. In fact, the modified form qad fa'ala embodies two phases: the (dynamic) process and its (static) result. 
TABLE 7.1 Temporal-aspectual distinctions in 'anna-clauses (cont.)

Verbal form

\section{Time reference}

\begin{tabular}{l|l|l}
\multicolumn{2}{c}{ Bounded lexeme } & Unbounded lexeme \\
\hline fa'ala & anteriority [7.6] & persistence [7.7] (stative lexemes) \\
\hline maf'ülVn & \multicolumn{2}{|c}{ resultativity-static [7.8] } \\
\hline qadfa'ala & resultativity-dynamic [7.9] \\
\hline
\end{tabular}

(7.1) fa-'alima l-qawmu'anna-hum yulāqūna l-qitāla

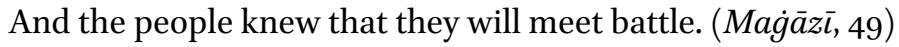

(7.2) fa- 'lam 'anna-hū yurìdu qatla-ka

Then know that he wants to kill you! (Kalìla wa-Dimna, 109)

(7.3) 'álim-hum 'annī sä̀irun 'ilay-him

Make them know that I am going to them! (Riwāyāt 2, 11)

(7.4) fa-lammā ra'ā l-rağulu 'anna l-diba quașidun naḥwa-hū

And when the man saw that the wolf was proceeding toward him ... (Kalïla wa-Dimna, 63)

(7.5) wa-'arafa 'anna-hū qad 'awqa'a fì nafsi-hı̀ mà țalaba wa-'anna l-'asada sa-yahdaru l-țawra wa-yatahayya'u la-hū

And he knew that he had planted in his mind what he wished, and that the lion will be wary of the ox, and will get prepared for him. (Kalïla waDimna, 95)

(7.6) 'uhbira 'anna 'amra bna sālimin wa-'aṣhạāba-hū rāḥū 'amsi

He was informed that 'Amr b. Sālim and his companions had gone yesterday. (Maj̄̄āi, 205)

6 The verb sāra may have either a bounded or an unbounded reading (i.e., 'to go away, depart': 'to go'). In [7·3], sä'iran is followed by the complement 'ilay-hi which specifies the destination of the going, thus the participle is interpreted as bounded. 
(7.7) 'innā nahšā yā rasūla llāhi 'an yazunna 'aduwwu-nā 'annā karihnā lhurūğa 'ilay-him ğubnan 'an liqāì-him

We fear, O Messenger of God, that our enemy will think that we did not want to come out to them out of fear of encountering them. (Magia żi, 210)

(7.8) fa-'awwalu mā 'awqa'a fì rü'-'̄'anna māl-ì mahfüzun 'alay-ya The first thing that struck my mind is that the preservation of my wealth is incumbent upon me (lit. 'that my wealth is preserved upon me'). (Buhalä', 78$)$

(7.9) ğìtu'uhbiru-ka'annì qad 'àmantu bi-llāhiwa-bi-rasūli-hīmuhammadin I came to inform you that I have become a believer (lit. 'that I have believed') in God and in his Messenger Muhammad. (Sira 1, 230)

The meaning of the verbal form is not only affected by the lexico-grammatical features described above. Quite often, the surrounding context or other pragmatic features are involved in its interpretation. For instance, repetition or presupposition seem to explain cases in which yaf'alu forms, instead of indicating posteriority with bounded lexemes, indicate concurrence. In these cases, yaf'alu refers to a situation whose 'actual referential concern' is extended over a period of time including the one indicated in the main clause. ${ }^{7}$ What calls for the 'still actual or relevant' interpretation of yaf'alu is its being conceived or presented as given or backgrounded. Consider, for instance, the following example:

(7.10) wa-sa'altu 'an-i l-muġannīna 'ayna yağtami'ūna [...] wa-qad balaġa-n̄̄ 'anna l-qawma yağtamiüna inda-ka

And I asked about the singers, where do they gather [...] I came to know that the people gather at your [place]. (Riwāyāt 1, 17)

The verb yağtami'üna in the substantival clause repeats the same information that was already mentioned in the question 'where do they meet', and whose abiding actuality and relevance are in fact presupposed by it. It indicates a frequentative situation taking place within the time frame indicated by qad

7 Janssen, Preterit as Definite, 168-169, explains the use of the present tense in such cases where the event 'does not coincide temporally with the time the sentence is spoken', as indicating 'actual referential concern to the speaker from his vantage point'. See also below 9.2.1. 
balaga-nī. The same frequentative meaning of yaf'alu with bounded lexemes is also observed in generic 'anna-clauses, which by definition refer to information that is presented as common ground shared by all:

(7.11) yā 'ağaban man ra'ā 'aw sami'a 'anna l-buzāta tahtațifu l-g̈ilmāna O how astonishing! Who [ever] saw or heard that falcons snatch children. (Kalïla wa-Dimna, 119)

As opposed to the frequentative yaf'alu, a generic participial form, whether active or passive, yields a static meaning of the verbal situation, due to the nonphasal contour marked by this grammatical form:

\section{(7.12) kāna bi-yaqūnin ma'lūman 'anna l-zamāna muḥdațun It was surely known that time is created. (Ta'rih 1,18$)$}

Substantival 'anna-clauses also feature compound forms with the anterior kāna. The situation expressed by kāna yaf'alu is located within a time span previous to the one indicated in the main clause; the situation expressed by kāna facala is located at a point in time previous to the one indicated in the main clause. Thus, kāna fáala carries a double marking of anteriority: it accentuates the anterior meaning already indicated by the simple fa'ala (see above 5.1):

(7.13) i'lam 'annìmundu yawmi waladtu-hā [...] kuntu'arfa'u min daqìqi kulli 'ağinatin hafnatan

Know, ever since I gave birth to her [...] I used to take a handful of flour from every piece of dough. (Buhalä, 55)

(7.14) fa-'ahbara-nā 'anna muhammadan kāna 'arada li-'iri-nā fì bad'ati-nā And he informed us that Muhammad had been observing our caravan since we started our [journey]. (Maj̄àzí, 28)

In my corpus, the negated forms lā yaf'alu, mā fa'ala, and lam yaf'al were attested in 'anna-clauses. The negative particles do not seem to have special bearing on the temporal interpretation of the verbal form: with bounded lexemes, lā yaf'alu has a posterior time reference, whereas with unbounded or stative lexemes, it has a concurrent meaning:

(7.15) wa-waqa'a fìnafsi-hĩ ’anna-hū là yarğíu 'ilā makkata It occurred to him that he is not going back to Mecca. (Mag் $\bar{a} z \bar{\imath}, 36)$ 
(7.16) ma'a 'annì là 'āmanu 'an takūna l-dāiratu 'alay-kum Along with that, I am not sure that you will have any success. (Maġāzi, 63)

The negated forms $m \bar{a}$ fa'ala and lam yaf'al were both found to be used in the same syntactic environment. A functional distinction between the two, as the one found in main clauses (see below 9.2.4), could not be observed in embedded clauses introduced by 'anna:

(7.17) fal-ya'lam 'anna-hū lam yu'ta fì dālika min qibali-nā wa-'innamā 'utiya min qibali ba'di nāqilī-hi 'ilay-nā

[The reader] should know that he was not given this [information] by us, but rather it was brought by some of its transmitters to us. (Ta'rih 1 , 7)

(7.18) wa-kāna man tahallafa lam yulam li-'anna-hum mā ḩarağù 'alà qitālin wa-'innamā harağù li-l-ìri

Whoever stayed behind was not scolded because they did not go out for a battle, but rather they set out for the caravan. (Maj $\bar{a} z \bar{\imath}, 21)$

On very rare occasions, 'anna-clauses follow desiderative verbs. In my corpus, such examples were only encountered in the Sahịh text, where 'annaclauses followed the verb wadda 'to wish', featuring both yaf'alu and fa'ala. Given the scarce evidence, it is hard to tell the exact functional distinction between both forms. However, the particular contexts in which the examples are found suggest that yaf'alu is used to refer to a hypothetic yet possible state of affairs, while fa'ala is used to refer to a counterfactual one (see also above $5 \cdot 3 \cdot 2)$ :

(7.19) wa-la-wadidtu'annì 'uqtalu fì sabìli llāhi

I wish that I would be killed for the cause of God. (Șahịh, 17)

(7.20) la-wadidtu 'anna-ka dakkarta-nā kullayawmin

I wish that you had reminded us every day. (Șahịh, 29)

In [7.19], 'uqtalu conveys the wish of the Prophet, which, at the time when pronounced, is still realizable. In [7.20], on the other hand, the wish dakkarta-na is answered with an explanation as to why the desired action is not feasible. 
Adjectival clauses may be adjoined directly to their nominal antecedent by means of juxtaposition, or they may join it via a mawșūl 'conjunctive pronoun', semantically representing the nominal antecedent and syntactically appositive to it. The mawșūl, here referred to by the general term 'operator', functions as the grammatical nucleus of the clause. In adjectival clauses where no such operator is explicitly present, one may assume, on the basis of paradigmatic opposition, that an implicit conjunctive pronoun occupies this slot. ${ }^{8}$ Another way of analyzing this construction is to view the close syntagmatic contact between the clause and its antecedent as the marker of the adjectival relation. ${ }^{9}$ Indeed, asyndetic adjectival clauses must immediately follow their nominal antecedent, and cannot be freely positioned in the text, unlike adjectival clauses which are headed by an operator (i.e., which incorporate their grammatical nucleus).

The pronominal operators which introduce adjectival (or, more generally, relative clauses) may be classified into two sets: (a) lladī and its inflection and (b) mā, man. The first set marks the grammatical categories of number, gender, definiteness, and sometimes case; the second set marks the distinction between persons and non-persons. The lladit-set often follows its nominal antecedent while the $m \bar{a} / m a n$-set seldom follows an explicit noun-phrase. Both types of adjectival clauses can occupy any syntactic position in a complex clause or in a nominal phrase in which a simple noun can occur.

The verbal paradigm in adjectival clauses consists of the same set of indicative forms found in substantival 'anna-clauses. The (implicit and explicit) operators introducing adjectival clauses do not impose a certain word order on the clause. I exclude from the present discussion conditional constructions headed by the operators $m \bar{a}$ and man: the overall configuration of these bipartite constructions, as well as their verbal paradigm (comprising, besides fáala, the apocopate $\left.y a f^{\prime} a l\right)$, are clearly distinct from the ones found in adjectival clauses.

\subsection{1 llad̄ì-clauses}

The pronominal operator lladī heads adjectival clauses whose antecedent is determined. It marks the categories of number and gender in the singular

8 Cf. Goldenberg, Allad̄īal-Mașdariyyah, 252.

9 For such a view of 'contact clauses' in English (e.g.: 'this is the boy we spoke of') see Jespersen, Modern English, 3, 81ff. 
and plural and, in addition, the category of case in the dual. The nominal antecedent of lladit-clauses may be either particular and specific or generic.

The verbal paradigm in lladi-clauses consists of simple, modified, and compound indicative forms. In principle, the same observations outlined above with respect to 'anna-clauses are pertinent also in lladit-clauses. There are, however, some modal nuances which appear to be more salient in this type of adjectival clauses.

The form yaf'alu indicates concurrence with unbounded lexemes:

(7.21) fa-taqaddama bi-hà 'ilā mawḍi í-hà llad̄ì yurìdu rasūlu llāhi 'an yaḍa'a$h \bar{a} f i-h i$

And he proceeded with it to the place where the Messenger of God wanted him to place it. $\left(\right.$ Mag $\left.\bar{a} z \bar{\imath}, 5^{6}\right)$

Repetition or presupposition may bring about a concurrent reading of yaf'alu with bounded lexemes:

\section{(7.22) man hādāa l-rağulu llad̄ìyaḍribu 'alay-ki bāba-ki kulla laylatin}

Who is this man that knocks at your door every night? (Sira 1, 335)

In [7.22], yadribu repeats the same piece of information that was already recounted in the previous narrative: fa-ra'aytu 'insānan ya'ti-hā min ğawfi llayli fa-yadribu 'alay-hā bāba-hā 'And I saw a man coming to her in the middle of the night and knocking on her door'. The adverbial phrase kulla laylatin makes it plain that the situation expressed by yadribu is frequentative. ${ }^{10}$ The same frequentative meaning of yaf'alu is also observed in lladit-clauses whose antecedent is generic:

\section{(7.23) wa-l-lāzibu huwa llad̄i yaltaziqu ba'ḍ-hū bi-ba'ḍin}

And the sticking [substance] is that which sticks to something else. (Ta'rīh 1, 88)

The difference between yadribu in [7.22] and yaltaziqu in [7.23] resides in the bounded or unbounded time span in which the frequentative repetition takes place, a span determined by the reference to a particular thus bounded

10 The presence of the adverb kulla laylatin is by no means a necessary condition for the habitual interpretation of $y$ af'alu. It provides an additional, explicit marking of this meaning. 
subject-entity ('this man') or to a generic thus unbounded subject-entity ('the sticking substance').

It is rather uncommon that yaf'alu within a lladit-clause indicates plain futurity. Consider the following example:

(7.24) 'andiğ hubz-ì llad̄ìyūdáu bayna yaday-ya

Prepare well my bread that is served to (lit. 'put in front of') me! (Buhalä', 84)

It is the imperative 'andig in the main clause that sets a future time reference for the situation in its entirety, while $y \bar{u} d a^{\prime} u$ retains a frequentative meaning. Rather than asserting a future occurrence, yaf'alu often conveys the meanings of possibility and ability:

(7.25) wa-man-i llad̄i yuhriğu-nā min-hu 'a-lasnā 'a'azza l-arabi wa-'aktarahum mälan wa-silăhan

Who will [be able to] take us out of it? Aren't we the strongest and most wealthy and armed among the Arabs?! (Riwāyāt 2, 36)

The simple form fa'ala has anterior meaning with dynamic lexemes. With stative lexemes it indicates persistence:

(7.26) naḥnu nu'ți-ka llad̄ì sa’alta

We will give you that which you asked for. (Mag்āzī, 373)

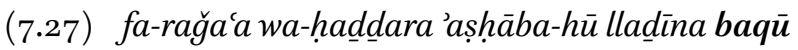

And he came back and warned his friends who stayed [there]. (Riwāyāt $2,14)$

While anteriority is doubly marked by the compound form kāna fa'ala (see [7.33] below), the modified qad fa'ala emphasizes the complete realization of the verbal situation, as shown in [7.28]. We recall that both these meanings, i.e., anteriority and completion, may be conveyed by fa'ala, although facala is not explicitly marked for any of them:

\section{(7.28) 'aštahì l-lạ̣ma lladì qad taharra'a}

I crave for the meat that has been overcooked. (Buhalä', 91)

Participial forms, both active and passive, are not very common in lladit-clauses. In my corpus, there were only examples in which the participle could be interpreted as concurrent, with both unbounded and bounded lexemes: 
(7.29) 'a-ra'ayta law qultu fì-ka ġayra llad̄ì 'anta la-hū mustaḥiqqun min-a lbāțili

Look at that, if I would have composed false poems about you, which you are not worthy of ... (Riwāya $\bar{a} t 1,7)$

(7.30) fa-mā llad̄ì anta fi-hi l-'āna muğmíun

What is it that you are decided about now? (Kalìla wa-Dimna, 67)

In cases when the time reference indicated in the main clause is (concrete or fictional) past, the distinction between yaf'alu and kāna yaf'alu in the adjectival clause is subtle: the compound form reproduces the expression of past time reference, whereas the simple form is temporally unspecified, indicating only a frequentative repetition:

(7.31) fa-harağat min madhali l-māì lladì kāna yahruğu min-a l-ġadìri And it came out from the mouth of the water that would flow out from the pond. (Kalïla wa-Dimna, 9o)

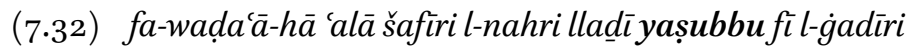
And they both laid it on the edge of the river that flows to the pond. (Kalïla wa-Dimna, 91)

Just as in 'anna-clauses, in lladi-clauses, the use of the compound form kāna fa'ala accentuates the anterior meaning indicated already by the simple form (see above 5.1):

\section{(7.33) wa-'ayna lladì kunta habbarta-nī bi-hì}

Where is that which you have told me about? (Riwāyāt 2, 193)

In my corpus, I have encountered very few examples of negated forms in llad $\bar{\imath}^{-}$ clauses. The attested negated forms are là yaf'alu and lam yaf'al, referring to future time and past time, respectively:

\section{(7.34) al-ḥamdu li-llāhi llậī là yubramu mā naqada}

Praise be to God; what He has destroyed will never be re-established. (Ta'inh 6, 3286) 
(7·35) wa-kāna qad balaġa fìl-buhliwa-l-takdiyati wa-fì katrati l-māli l-mabāli-

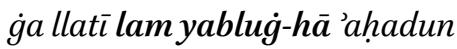

He has attained, through his greed and mendicancy and [his] great wealth, sums of money that no one has ever attained [before]. (Buhalä, $71-72)$

In [7.34], due to the divine nature of the antecedent, lāyaf'alu is interpreted as a certain prediction. In [7.35], due to the presence of a generic referee ('ahadun '[no]one'), lam yaf'al is interpreted as a sweeping negation of the past (see below 11.3). In both cases, the verbal form does not negate the occurrence of a specific future or past event, but rather affirms the validity of a general truth.

\subsubsection{Asyndetic Adjectival Clauses}

Asyndetic adjectival clauses, șifa 'descriptive' in the Arabic grammatical tradition, are not introduced by an explicit operator. Rather, they follow directly after their nominal antecedent, which may be analyzed as the nucleus of the clause (see above 7.3). The nominal antecedent in asyndetic adjectival clauses is not determined. It may be either particular and non specific or generic.

The verbal paradigm in asyndetic adjectival clauses consists of the same forms found in lladit-clauses. In general, the aspectual and temporal distinctions that were specified above with regard to 'anna-clauses are also observed in asyndetic adjectival clauses. Yet, this type of clauses features some particularities which deserve a discussion of their own.

With stative lexemes, yaf'alu indicates concurrence with the situation expressed in the main clause, whether the overall temporal frame is past or nonpast:

(7.36) wa-ğa'alū kullamā hāğa-hum 'ahadun min-a l-awsi wa-l-hazraği bišay'in yakrahūna-hū lam yamši ba'du-hum 'ilā ba'din

Whenever someone from 'Aws or Hazrağ provoked them with something they hated, they stopped (lit. 'began not') going to one another [for help]. (Riwāyāt 2, 14)

(7.37) ib'aț maī rağulan min țiqāti-ka yafhamu bi-l-'arabiyyati

Send with me one of your trustworthy men who understands Arabic! (Riwāyāt 2, 192)

The same concurrent meaning of yaf'alu is also evident with dynamic, unbounded lexemes: 


\section{(7.38) fa-laqiya mrảatan taḥmilu ța'āman}

And he came across a woman carrying food. (Sira 1, 320)

Rather than mere futurity, it is often the case that $y$ af'alu with bounded lexemes conveys the modal meanings of ability or possibility:

(7-39) 'arā fì hādihi l-ağamati samakan kațīran nașìdu-hū li-muddatin I see in this swamp many fish that we could fish for a while. (Kalila wa-Dimna, 84)

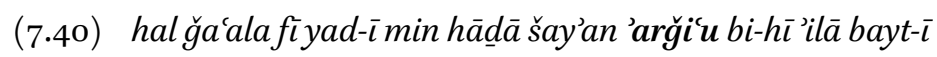

Did he thereby put anything in my hand I could take back to my home? (Buhalä) 49)

In certain cases the exact modal nuance expressed by yaf'alu is not easy to demarcate. Thus, the meaning of ability appears sometimes to be fraught with that of obligation. This is the case in [7.41]-[7.42], where people are appointed to some duty, specified in the adjectival clause:

(7.41) wa-sta'mala rasūlu llāhi 'alà l-ḥarasi muḥammada bna maslamata fì hamsina rağulan yațüfüna bi-l-'askari

The Messenger of God appointed Muhammad b. Maslama as the head of the guard of fifty men, who would go around the army [camp]. (Maḡāzi, 217)

(7.42) wa-'amara la-hum bi-hādimin yahdimu-hum wa-'abdin yasqī-him l$m \bar{a} a$

He ordered [to provide] them [with] a servant that would serve them and a slave that would provide them water. (Riwāyāt 1, 7)

In all the above examples, the interpretation of $y a f^{\prime} a l u$ as expressing plain futurity, devoid of modal nuances, does not seem to be supported by the context. However, the following example presents us with a different case:

(7.43) wa-'in lam taf'alū kāna la-hü fi-kum dabhun țumma bu'ițtum min ba'di mawti-kum fa-ğu'ilat la-kum nārun tuḥraqūna fi-hā

But if you do not act [as he calls you to] he will have you slaughtered; then you will be raised from the dead and put in fire, in which you will be burned. (Sir $a 1,326)$ 
Although not directly uttered by the Prophet, this is a prophecy stating the general divine plan. In this context, the statement is granted the status of an absolute truth and, consequently, conveys the utmost certainty regarding its future execution (cf. [7.34] above). Thus, compared with the other examples, we may say that tuhraqūna indeed functions as an assertion of future event.

Just as in substantival 'anna-clauses and adjectival llad̄it-clauses, in asyndetic adjectival clauses, fa'ala with stative lexemes indicates persistence, whereas with dynamic lexemes it indicates anteriority relative to the time frame established in the main clause:

(7.44) su'ila l-nabiyyu 'an 'ašyāà kariha-hä The Prophet was asked about things he detested. (Sahịh, 36)

(7.45) 'utiya hiraqlu bi-rağulin 'arsala bi-hì maliku ġassāna Heraclius was brought a man, whom the king of Gassān had sent. (Sạịh, 9)

The modified form qad facala, due to the bounding force of $q a d$, indicates anteriority with both stative and dynamic lexemes, relative to the time frame established in the main clause:

(7.46) ințaliq bi-nā 'ilā 'adnā mã̄i l-qawmi [...] bi-hā qalïbun qad 'araftu 'udūbata $m \bar{a} \bar{i}-h \bar{a}$

Let us reach the nearest point to the water of the people $[\ldots]$ in it there is a well, whose sweet water I have already come to know. (Majāzi, 53)

(7.47) fa-ğalasatā 'alā sarīin qad wuḍi'a la-humā

They both sat on a bedstead that had been put down for them. (Riwāyāt 1, 24)

We observe a special use of fa'ala and qad fa'ala in asyndetic adjectival clauses whose nominal antecedent functions as an internal object, derived from the same root as the main verb (either in the form of a verbal noun or a nomen vicis). In these cases, fa'ala and qad fa'ala do not refer to an anterior situation, but to the immediate consequence of the preceding event. The nominal antecedent does not refer to a particular entity but to an outstanding exemplar of a certain type or kind ('such a $\mathrm{x}$ that'): 
(7.48) fa-șāḥa șayhatan sami'a-hā rahțu-hū

He shouted [such] a shout that it reached his troop (lit. 'that his troop heard it'). (Riwāayāt 2, 24)

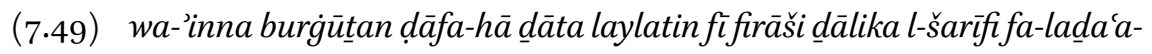
hü lad'atan 'ayqazat-hu

And a flea was her (i.e., the ant's) guest one night, in the bed of that distinguished man, and he stung him [such] a sting that it awakened him. (Kalïla wa-Dimna, 93)

(7.50) fa-'inna-hū qad 'afrața fí 'amri l-țawri 'ifrātan qad hağğana ra'ya-hū For he had exaggerated in the matter of the ox [such] an exaggeration that made him (lit. 'his mind') scorned. (Kalïla wa-Dimna, 81)

In my corpus, the participle occurred only in very few cases as the predicate of an asyndetic adjectival clause. With bounded lexemes, active participial forms were found to indicate posteriority relative to the time frame established in the main clause. Compared to yaf'alu, the participle seems to not be imbued with the modal nuances of possibility and obligation; rather, a straightforward reference to the immediate or expected future is expressed by the participle:11

(7.51) wa-qad ruwiya 'an rasūli llāhi [...] 'axbārun 'anā dِākirun min-hā ba'da mā hadara-nī

There have been reports transmitted on the authority of the Messenger of God [...] of which I shall mention some that have reached me. (Ta'rin $1,61)$

Asyndetic adjectival clauses also exhibit compound forms. As elsewhere, kāna indicates an anterior point of reference (relative to the main clause), while the predicative forms fa'ala and yaf'alu are left to indicate the aspectual opposition between bounded/incidental and unbounded/habitual situations. The compound kāna fáala accentuates the meaning of anteriority whereas kāna qad facala marks both the anteriority and completion of the verbal situation:

11 For the notions of 'immediate future' or 'expected future', referring to 'events which are expected to occur in the near future, or to those which have been prearranged', see Bybee, Perkins, and Pagliuca, Evolution, $249 \mathrm{ff}$. It may be that with immediate future one is not concerned with the expression of predictions in the strict sense, but with 'assertions announcing the imminence of an event' (273), see also below 9.2.1. 
(7.52) hādihi riwāyatu l-kalbiyyifí qașāida kațīratin kāna yaqūlu-hā fi-hi This is al-Kalbì's version as to many poems he used to compose with regard to him. (Riwāyāt 2, 187)

(7.53) fa-stahrağa sayfan kāna la-hū wa-dira hạadìdin kānā dufinā fì nāhiyati l-mazraiati

And he drew out a sword he had and an iron armor that had been buried at the corner of the field. (Mag்äzi, 208)

(7.54) fa-lammā stațqala nawman 'amadat 'ilā sammin kānat qad hayya'athu

And when he fell into heavy sleep, she took up a poison that she had fixed. (Kalīla wa-Dimna, 78 )

In my corpus, asyndetic adjectival clauses featured the negation of yaf'alu with either $l \bar{a}$ or $m \bar{a}$. As is the case in main clauses, māyaf'alu was mostly used with stative and unbounded lexemes, thus indicating concurrence with the main clause (see also below 9.2.4):

(7.55) la-qad-i staqbalta-nì bi-’amrin mā 'arā-ka qulta-hū li-'ahadi raciyati-ka mundu walayta

Indeed, you have welcomed me with something I don't think you have said to anyone of your citizens (lit. 'herd') since you became the ruler. (Ta'rīh 3, 1145)

As already illustrated above, the negative lāyaf'alu, like the affirmative yaf'alu, may convey various degrees of certainty. The interpretation of the form as expressing a lower or a higher degree of certainty is determined, inter alia, by the particular or generic context in which the clause is situated. Consider the following examples:

(7.56) hattā habasa-hüfìmaḥbasin là yadhuulu 'alay-hi fi-hi'ahadun To the point that he put him in prison in which no one would/could come to [visit] him. (Riwāyāt 2, 187)

(7.57) 'inna min-a l-šağari šağaratan lā yasquṭu waraqu-hā There is a kind of tree (lit. 'a tree among the trees') whose leaves never fall. (S. Sặh 1, 25) 
In the narrative from which [7.56] is extracted, the characterization of the prison as such that 'no one would/could visit' is invalidated later in the story when someone in fact visits the person in prison. By contrast, the generic statement in [7.57] conveys a fact which cannot be invalidated.

The same consequential meaning indicated by fa'ala and qad fa'ala following an internal object was also attested with the negated form mä fa'ala. The negated form lam yaf'al, also when following an internal object, was used to indicate past negation:

(7.58) wa-qad fuğíat nafs-ì bi-fağı̌áatin māa 'așabtu min-hā 'iwadan My soul was afflicted by [such] a disaster, for which I could not find consolation. (Kalïla wa-Dimna, 120)

(7.59) wallāhi la-'in 'ištu la-ka la-'aqtulanna-ka qitlatan lam yuqtal-hä 'arabiyyun qattu

By God, If I outlive you [r plot], I will kill you in a way by which no other Arab has ever been killed yet. (Riwāyāt 2, 195)

\subsection{3 mā-clauses}

The pronominal operator $m \bar{a}$ represents non-persons. The thing or matter indicated by $m \bar{a}$ may have either particular or generic, specific or non-specific reference. The clause headed by $m \bar{a}$ rarely follows an explicit nominal antecedent. However, it is often the case that the clause is preceded or followed by a prepositional min-phrase, which serves to specify the lexical content represented by the grammatical nucleus $m \bar{a}$ (see [7.63] and [7.72] below). ${ }^{2}$ Clauses headed by $m \bar{a}$ may occur independently or as genitive complements of prepositions or nouns in the construct state. ${ }^{13}$

The verbal paradigm in relative $m \bar{a}$-clauses comprises simple, modified, and compound indicative forms. In the following, the semantic oppositions between these will be discussed.

With unbounded (including stative) lexemes, yaf'alu indicates concurrence, whether the temporal frame established in the main clause is past or nonpast:

12 The degree or kind of specificity indicated by a min l-bayān phrase vis-à-vis the definite article and the tanwin is a subject well worthy of study.

13 Though relative $m \bar{a}$-clauses may be paraphrased by substantives, they are distinct from other substantival $m \bar{a}$-clauses, in that they do not express content ( $m \bar{a}=$ 'that') but refer to an entity $(m \bar{a}=$ 'what'). 
(7.6o) kāna rasūlu llāhi 'id 'amara-hum 'amara-hum bi-mā yuṭīqūna Whenever the Messenger of God ordered them, he ordered them to do what they were able to bear. (Șahịh, 13)

(7.61) fa-qad yahḍuru țáāma-kum l-šayhu llad̄i qad dahaba famu-hū wa-lșabìyu llad̄i lam yunbat famu-hū wa-'aț 'imū-hum mà ya'rifüna For the old man whose teeth (lit. 'mouth') are already gone, and the boy whose teeth haven't come out yet, may well attend your meal, so provide them with what they are accustomed to! (Buhalä, 105)

Also with bounded lexemes, yaf'alu may indicate concurrence. In such cases, the content expressed by yaf'alu is presupposed or backgrounded, as in the following example:

(7.62) fa-lam ya'rid 'alay-hi l-ța'āma wa-nahnnu na’kulu [...] fa-qultu subḥana llăhi law danawta wa-'așabta ma'a-nā mim-mā na'kulu

He did not offer him anything to eat while we were eating [...] so I said: 'God forbid! If you could draw near us and have some of what we are eating.' (Buhalä', 38)

The speaker refers to a state of affairs that was previously mentioned, and that is presented as still abiding at the time of the utterance. The concurrent reading of yaf'alu is occasionally corroborated by adverbs referring to the present situation of speech:

(7.63) wa-'innamā kānat ǐšat-ì 'ilā l-yawmi mim-māa 'așīdu hāhunā min-a lsamaki

For my living until today was [based] on those fish I catch here. (Kalïla wa-Dimna, 83)

It is interesting to compare [7.62] and [7.64], where the same lexical content, i.e. 'to eat', is expressed by yaf'alu:

\section{(7.64) 'innī qad taraktu la-ka mā ta'kulu-hū 'in hafazta-hū}

I have left you what you could eat (i.e. live from) if you are careful of it. (Buhalä', 73)

In [7.64], as is usually the case with bounded lexemes, yaf'alu indicates posteriority. The meaning of futurity is nevertheless coupled with that of possibility: the certainty of the prediction expressed by ta'kulu-hū is not only limited by the 
subjective epistemological position of the predictor, but also by the following conditional. A somewhat different position for making predictions is assumed by the first person, when committing himself to doing something. In this case, the prediction is inevitably tinted with the subjective intention of the executer (see also below 9.2.1):

(7.65) yāa 'àla 'awsin qātilū 'alā l-'aḥsābi wa-șna'ū mițla mā 'aṣna'u O people of 'Aws, fight for honor (lit. 'for the noble descents') and do as I will do! (Maj̇̄̄zí, 224)

When generically interpreted, yaf'alu is not located in a time relative to the temporal frame established in the main clause. The generic yaf'alu indicates a concurrent meaning, inasmuch as it conveys a general truth that is valid for all times (see below 11.3). This temporal relation is observed with both bounded and unbounded lexemes, the difference is that the first have a (dynamic) frequentative reading while the latter have a static one:

(7.66) māta ka-mā yamūtu l-nāsu

He died [the same way] as people die. (Riwāyāt 2, 21)

(7.67) lammā qadima 'alā l-nu'māni șādafa-hū lā māla inda-hū wa-lā 'atẫta wa-lā mā yaṣluḥu li-malikin

When he arrived to Nu'mān he found him with neither money nor property or whatever is appropriate for a king. (Riwāyāt 2, 187)

To see the difference between particular and generic reference, it is interesting to compare [7.75] below and [7.66]. In the first case, the characterization of the particular l-nāsu as 'those who used to stand at the door' is limited in time, while in the latter case the characterization of the generic l-nāsu as 'those who die' is an a-temporal fact.

The simple form fa'ala indicates with stative lexemes a persisting situation, as shown in [7.68]. With dynamic lexemes, fa'ala indicates anteriority relative to the time frame established in the main clause, whether that be past or nonpast, as shown in [7.69]:

(7.68) naf'alu yā 'abā l-qāsimi mà 'ạ̣babta

O 'Abū Qāsim, we will do what you want. (Maġāāi, 364) 
(7.69) 'a-là tahmusu mā 'aṣabta min banì l-nadìri ka-mā hamasta mā 'aṣabta min badrin

Will you not take one fifth of what you have taken [as booty] from Banū Nadiir, the same as you took one fifth of what you had taken [as booty] from Badr? (Majīāzī, 377)

As elsewhere, also in $m \bar{a}$-clauses the modified form qad facala, with both bounded and unbounded (stative or dynamic) lexemes, depicts a static situation resulting from a dynamic process:

(7.70) 'așāba-nā min-a l'amri mà qad 'alimta

The matter that you know (lit. 'you have come to know') of has befallen us. (Maj̇̄zzì, 411)

(7.71) wa-'innā nahšā 'alay-ka wa-'alà qawmi-ka mā qad dahala 'alay-nā We fear for you and your people [that you will face] that which has befallen us. (Sïra 1, 252)

The example below illustrates a special case: the modified form qad mada does not refer to a point in time previous to the narrative time indicated by qāla; rather, it indicates anteriority relative to the time of reporting itself:

(7.72) fa-qāla bnu 'isḥāqa mā qad maḍa dikru-hū Ibn 'Isḥāq said what has already been mentioned. (Ta'rīh 1, 192)

Just as yaf'alu, the active participle fácilun may indicate either concurrence with unbounded lexemes or posteriority with bounded ones. The differences are that: (a) fácilun indicates a static rather than a frequentative situation, and (b) the future indicated by fä ilun is not fraught with modal nuances such as ability and obligation. Rather, this form indicates imminence or an expected future (see also [7.51] above):

(7.73) wa-'in zafirtum lam nanam 'an-i l-țalabi [...] wa-yašg̉al-kum min šảninā mà 'antum-u l-āna min-hu hà̃ūuna

If you overcome [us], we will not rest [from] looking for revenge [...] and you will be troubled by our matter which you are now free of [concern]. (Riwāyāt 2, 40) 
(7.74) wa-qad ġadat qurayšun fa-ğalasū fì 'andiyati-him yantazirūna mà 'abū ğahlin fã iilun

Qurayš had already had breakfast and sat in their assemblies to watch what 'Abū Ğahl was about to do. (Sira 1, 190)

In $m \bar{a}$-clauses the compound form känayaf'alu is primarily used to refer to an unbounded or recurring situation, extending over a period of time previous to the one indicated in the main clause:

\section{(7-75) fa-waqafa 'alā mā kāna yaqifu l-nāsu 'alay-hifíl-qadìmi}

And he stood [at the door] in the same way people used to stand in old times. (Riwāyāt 1, 252)

We observe a less common use of the compounds kāna yaf'alu and kāna fāilan in $m \bar{a}$-clauses, where kāna serves to indicate a hypothetic meaning. In these cases, the $m \bar{a}$-clause functions as the topic of a complex clause, whose following comment is preceded by $f a$-. This structure, similar to topicalizations marked by 'ammā $f a-$, is reminiscent of conditional constructions. The resemblance, however, is syntactic rather than semantic, since the meaning of implication clearly does not emerge in these structures:

(7.76) fa-mā kuntum turīdūna 'an taṣna'ū yawman min-a l-dahri fa-min-a l'āni

And that which you would have liked to do some day—now is the time [to do it]. (Mag் $\bar{z} z \bar{\imath}, 364)$

Anteriority is doubly marked with the compound form kāna fáala. The compound kāna fáala is not only used in the narrative, relative to the past or the fictional time indicated by fa'ala, but also in the dialogue, relative to the present time of speech:

(7.77) wa-salaba-hū mā kāna 'àtā-hu min mulki l-samā̉i l-dunyā wa-l-'arḍi He deprived him of the rule that he had (lit. 'had come to him') over the lower heaven and the earth. (Ta'rin 1, 101)

(7.78) qad 'alimta haqqa-ka 'alay-ya wa-widda mā bayn-īwa-bayna-ka wa-mā kuntu ğa'altu la-ka min nafs-ī wa-dimmat-ì ayyāma ’arsala-nì 'ilay-ka l'asadu

You know my duty to you, and the affection between us, and my devotion (lit. 'soul') and responsibility for you in the days when the lion sent me to you. (Kalïla wa-Dimna, 96) 
The contrast between a dynamic aspect marked by yaf'alu and a static aspect marked by the participle is most evident in kāna-compounds, comparing, for instance, [7.75] above and [7.79] below:

(7.79) tabayyana la-hum mā kāna 'an-hum mustatiran

They became aware of what had been concealed from them. (Ta'ring 1 , 94)

The static (or non-phasal) structure of the verbal situation is indicated by both the active and passive participles with the anterior kāna. In [7.80], the topical $m \bar{a}$-clause refers to a situation (kāna mulattahan) which came about prior to the past event indicated in the comment (dulika):

(7.80) fa-mā kāna min-hā mulațahan dulika d̄ālika dalkan šadìdan

And that part of it (i.e., of the thick bread) that had been smeared - this was rubbed well. (Buhalä', 85)

Topical $m \bar{a}$-clauses exhibit the hypothetic use of kāna also with the participle (see [7.76] above). In [7.81], the imperative $f a-s ̦ n a-h u$ in the comment clause establishes a future time frame, in which the situation indicated by kunta șānican could be realized:

\section{(7.81) fa-mā kunta șāni'an 'id ā hallū bi-ka fa-ṣnac-hu}

Then do what you would do when they stay with you! (Magia żi, 204)

Clauses headed by $m \bar{a}$ feature the negation of yaf'alu with $l \bar{a}$ (the negation with $m \bar{a}$ is apparently precluded in order to avoid homonymy). With both bounded and unbounded lexemes lāyaf'alu was found to indicate the meaning of impossibility:

(7.82) 'inna hādā l-'a'mà l-mulhida l-zindīqa qad hağā-ka fa-qāla bi-'ayyi šay'in fa-qāla bi-mā là yanțuqu bi-hì lisān-ì wa-là yatawahhamu-hü fikr-ì This blind, unbelieving infidel has lampooned you [in verse]! He said: 'By saying what?' He replied: 'By [saying] what my tongue cannot utter and my mind (lit. 'thought') cannot imagine.' (Riwāyāt 1, 261)

Past negation in $m \bar{a}$-clauses is indicated by the negated form lam yaf'al. Here, again, one can assume that the use of the negative particle $m \bar{a}$ is precluded since it is homonymic with the pronominal operator $m \bar{a}$ : 


\section{(7.83) li-'anna-humā qarawiyāniyasîfāni mā lam yarayā}

Because they both are countrymen, describing what they have not seen. (Riwāayāt 2, 176)

\subsection{4 man-clauses}

The pronominal operator man represents persons. The person referred to by man is either particular or generic, specific or non-specific. Clauses headed by man rarely follow an explicit nominal antecedent (for an exception see [7.87] below). The identity of the person represented by man is often specified by a prepositional min al-bayān phrase (see [7.85] and [7.97] below). Adjectival man-clauses occur independently or as genitive complements of prepositions or nouns in the construct state.

The verbal paradigm in adjectival man-clauses consists of simple, modified, and compound indicative forms. The verbal forms in man-clauses present some deviations from the temporal-aspectual distinctions observed in other embedded clauses. These, as well as the common uses, will be henceforth discussed.

With unbounded (including stative) lexemes, yaf'alu indicates concurrence with the time frame established in the main clause:

\section{(7.84) iğtama'a nāsun fì l-masğidi mimman yantahilu l-iqtișāda fì l-nafaqati} In the mosque, there gathered people who profess the economy of expenditure. (Buhalä, 53 )

With bounded lexemes, yaf'alu is normally interpreted as having a posterior time reference. As noticed above, the future meaning of $y a f^{\prime} a l u$ is fraught with modal nuances, ranging from ability, possibility, or obligation - that is, lower certainty - to absolute validity or certainty as to the execution of the verbal event. The degree of certainty is affected by the epistemological position or authority of the predictor/executer, allowing him to make more or less 'objective' predictions. The following examples illustrate the difference between prediction made by a particular person, whose knowledge and ability to foresee the future is limited, and prediction made by a predictor who holds an absolute knowledge as to future happenings:

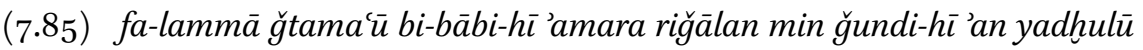
l-ḥäira llad̄i banā tumma yaqtulū kulla man yadḩulu 'alay-him min-a l-yahüdi

And after they gathered at his door, he ordered men from among his soldiers to go into the cistern that he had built, and then kill all the Jews who will/may enter upon them. (Riwāyāt 2, 11-12) 
(7.86) wa-la-'amr-ì la-'in kāna muhammadun kādiban 'inna fíl-'arabi la-man yakfi-nā-hu

By my life, if Muhammad is a liar there are among the Arabs those who will/can save us from him. (Mag் $\bar{a} z \bar{\imath}, 42-43)$

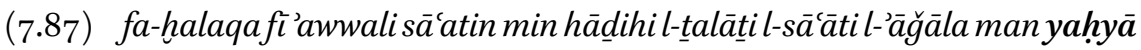
wa-man yamūtu

And in the first one of these three hours he created the [fixed] terms, who will live and who will die. (Tarih 1,20$)$

The pronoun man often represents a generic entity. In such cases yaf'alu does not refer to a point in time relative to the one established in the main clause, but to a situation which is temporally unbounded, and which therefore appears as concomitant with any other point in time:

(7.88) fa-daqqa 'alay-hi l-bāba daqqa wātiqin wa-daqqa mudillin wa-daqqa man yahăäu 'an yudrika-hū l-'asasu

He knocked on his door [with] the knock of a confident person, and the knock of a presumptuous person, and the knock of someone afraid that the night guard would catch him. (Buhalä, 66)

The use of the form fáala in man-clauses deviates to some extent from its use in other types of embedded clauses. With stative lexemes, facala indicates a persisting situation. The same meaning is also indicated by the negated form lamyaf'al:

(7.89) 'ayyu l-islāmi hayrun qāla tuțimu l-ța'āma wa-taqrảu l-salāma 'alā man 'arafta wa-man lam ta'rif

Which [way of practicing] Islam is best? He said: 'Serve food and greet with "Peace [be upon you]" those whom you know and those whom you don't know.' (Șahịh, 11)

With dynamic lexemes, fáala may refer not only to anterior situations but also to posterior situations:

(7.9o) wa-'ašära 'ilay-hi man hạạ̣ara-hū wa-qālū uskut fa-sakata Those who brought him in signaled to him and said: 'Shut up!' So he became silent. (Riwāàāt 1, 254) 
(7.91) fa-lammā nazala fì l-nahri kāda yaġraqu fa-ra’ā-hu qawmun min 'ahli l-qaryatifa-'arsalū 'ilay-hi man-i stahrağa-hū

And when he went down in the river he almost drowned. Then, some people from the village saw him and sent to him someone who pulled him out. (Kalïla wa-Dimna, 63-64)

In [7.91], the event of 'pulling out' clearly follows the event of 'sending'. Notice that the syntagmatic order of the clauses conforms with the chronological order of the events: the embedded man-clause follows the main verb and depicts the next event in the narrative chain.

In generically interpreted man-clauses, fa'ala is also used to indicate persistence. In this case, however, persistence does not coincide with a particular period of time, but is interpreted as an ever-enduring state:

(7.92) al-muslimu man salima l-muslimūna min lisāni-hīwa-yadi-hì

The Muslim is one who the Muslims are safe from [the harm of] his tongue and hand. (Șahịh, 11)

Since facala in generic man-clauses does not indicate a temporally bounded event, one may encounter such cases where it interchanges with yaf'alu, the typical form in generic clauses:

(7.93) țalātun man kunna fi-hi wağada ḥalāwata l-imāni [...] wa-man yakrahu 'an ya'ūda fì l-kufri ba'da 'ị 'anqada-hū llāhu ka-mā yakrahu 'an yulqā fì l-nāri: (in the title) bābu man kariha 'an ya'ūda fíl-kufri

There are three [traits] that whoever has them in him finds the sweetness of belief [...] and [the third of which is] one who hates to revert to infidelity after God has saved him, the same way as he hates to be thrown into the fire [of hell]:: The chapter on he who hates to revert to infidelity (Șahịh, 13)

Adjectival man-clauses often follow the elative 'awwal '(the) first' as genitive complements. ${ }^{14}$ In these cases, too, facala is not used to indicate anteriority (unless the genitive construction is preceded by kāna):

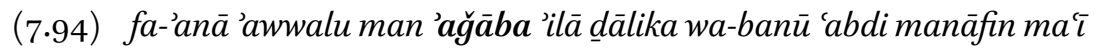
Then I am the first to agree to it and Banū 'Abd Manāf are with me. (Maḡāzī 1, 200)

14 Cf. Reckendorf, Syntaktischen Verhältnisse, 2, 605. 
Another special use of fáala in man-clauses is observed in 'tautological' constructions such as illustrated in the next example:

(7.95) 'anta 'arsalta 'ilā qurayšin 'an tarǧi'a fa-rağa'a man rağa'a wa-maḍā man maḍa

You have instructed (lit. 'sent to') Qurayš to come back, so some came back (lit. 'he who came back came back') and some went on (lit. 'he who went on went on'). (Maj̇̄ā̄i 1, 45)

It appears that man is used in these cases to mark the underspecification of a class of referents, relative to other markers of nominal determination: man rağa'a is both indefinite (as opposed to al-rāăíu), and not quantified (as opposed to rāğíun/rāğíūna). ${ }^{15}$

I could not find a single example in my corpus in which qad fa'ala was employed in a man-clause. ${ }^{16}$

In my corpus, there were very few examples in which the participle was attested in man-clauses. In the following example, the participle, with a bounded lexeme, is employed to indicate an immediate future (see [7.51] and [7.74] above):

(7.96) maqrūnan dikru kulli man 'anā dākiru-hū min-hum fì kitāb-ì hādāa bi-

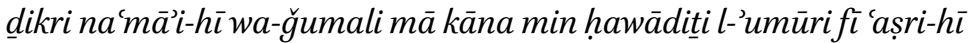

To the account on everyone whom I mention in this book of mine, an account on his graces and a summary of the events which took place at his time is added. (Ta'rih 1,5$)$

The compound forms are employed in man-clauses as elsewhere: kāna yaf'alu indicates an unbounded, recurring or ongoing, situation, which extends over a period of time previous to the one indicated in the main clause. With dynamic lexemes, kāna fa'ala depicts an event that has occurred prior to the time frame established in the main clause, and with stative lexemes, a situation that still persists at that time:

15 Cf. Fischer, Classical Arabic Grammar, 218, who describes the 'uncertainty' expressed by man in these cases.

16 Reckendorf, Arabische Syntax, 432, adduces one example of qad fa'ala within a manclause: 'inna 'awsan man qad 'arafta 'Aws ist einer, den du kennst'. 
(7.97) fa-bnu'ubayyin lā yanșuru ḥulafẳa-hū wa-man kāna yamna'u-hū mina l-nāsi kulli-him

Ibn 'Ubayy would not help his allies and those who used to protect him

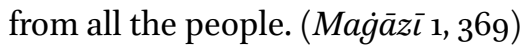

(7.98) wa-ma'a rasūli llāhi 'ammu-hū ḥamzatu bnu 'abdi l-muțtalibi wa-'abū bakri bni abì quhāafata l-șiddīqu wa-'aliyyu bnu 'abì țālibin fì riğāli min-a l-muslimina mimman kāna 'aqāma ma'a rasūli llāhi bi-makkata

And with the Messenger of God were his uncle Hamza b. 'Abd alMuțtalib, 'Abū Bakr b. 'Abī Quhạâa the righteous, and 'Alī b. 'Abī Ṭālib, from among the Muslims who stayed with the Messenger of God in Mecca. (Sira 1, 225)

The same as the affirmative yaf'alu (see [7.88] above), the negated là yaf'alu also indicates a temporally unbounded situation in generically interpreted man-clauses:

\section{(7.99) wa-lā rảya li-man lāyuțāu}

There is no [significance to the] opinion of one who is not obeyed. $\left(\right.$ Maḡā $\left.z \bar{\imath}, 5^{2}\right)$

\subsection{Adverbial hịna-clauses}

The operator hina 'at the time when' heads a temporal clause. Like other timedenoting nouns with adverbial function, hina is in the construct state. The clause that follows it functions as its genitive complement.

Adverbial hina-clauses follow the main clause as a rule. ${ }^{17}$ The temporal relation expressed by hina is that of coincidence or immediate adjacency between two events: the event in the main clause and the event in the embedded hinaclause are presented as realized within a common time frame, whether in reality they precede, follow, or overlap each other. ${ }^{18}$ The verbal forms occurring

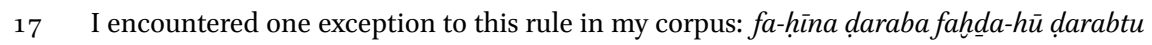
ra'sa-hū bi-sayfin (Riwāyāt 2, 23) - And right after he hit his thigh, I hit his head with a sword.'

18 Declerck, When-clauses, defines the semantics of when as that by which a 'common frame' or 'coreferentiality' between two intervals of time is established. When, accordingly, does not express strict overlapping, but rather, 'all that is required is that the two [situations] should be conceived as falling within the same interval' (245). 
in hina-clauses are fa'ala and yaf'alu, nearly always in the affirmative. ${ }^{19}$ While hina facala indicates recentness with respect to the event in the main clause, hina yaf'alu indicates simultaneity, with both bounded and unbounded lexemes:

(7.100) fa-nțalaqa hịna 'atā-hu kitābu-hū

And he left as soon as his letter had reached him. (Riwāyāt 2, 193)

(7.101) law nazarta 'ilay-hi hịna yadhulu 'alay-ka

If you look at him, when he enters upon you ... (Kalïla wa-Dimna, 95)

(7.102) 'in ra'ayta l-'asada hīna yanzuru 'ilay-ka

If you see the lion, when he looks at you ... (Kalïla wa-Dimna, 109)

The distinction between hina and other time-denoting operators, such as lam$m \bar{a}$ 'after' and baynā/baynamā 'while', is described in the grammatical literature mostly in semantic terms. According to Reckendorf, lammā and hìna are different in that the first indicates the Zeitpunkt in which the event occurs, thereby marking a clear boundary between two succeeding events, whereas the latter indicates a short or long Zeitraum in which the event occurs. ${ }^{20}$ Beeston defines the functional contrast between lammā and hina as that between the marking of 'past time' (with stative aspect) and the marking of 'actual simultaneity'.21 Though not incorrect, these descriptions overlook two important syntactic facts: (a) lammā co-occurs only with fáala, while hìna co-occurs with both fa'ala and yaf'alu; and (b) lammā-clauses come first in the chain while hina-clauses nearly always follow their matrix clause. In fact, from a syntactic point of view, lammā-clauses are better compared with baynā/baynamāclauses, since both types of clauses partake in structures of mutual dependency as setting or background units (see below 8.4 and 10.4). Clauses headed by hina, on the other hand, are embedded in the main clause and function as local adverbial expansions. Also from a semantic point of view, the definition of the

19 Reckendorf, Syntaktischen Verhältnisse, 2, 662, adduces one example in which hìna is followed by a negated form: numsiku l-hayla [...] hịna lā yumsiku-hā 'illā l-șuburu 'We hold the horses $[\ldots]$ as only the patient hold them'. In this case, it is not negation but restriction that is marked by the $l \bar{a}$ 'illā structure.

20 Reckendorf, Syntaktischen Verhältnisse, 2, 662.

21 Beeston, Arabic Language, 99. Beeston ascribes to lammā the same 'conversive force' he ascribes to the modifier $q a d$, transforming the dynamic aspect of the 'suffix-set' verb into a static one. 
contrast can be refined: while lammā marks the transition from one interval to another ('after'), and baynā/baynamā the inclusion of one interval in another ('while'), hina indicates a temporal adjacency which may extend from a single point of contact (with fa'ala) to total overlapping (with yaf'alu). These observations are summarized in the table below:

TABLE 7.2 The contrast between hịna, lammā, and baynā/baynamā

\begin{tabular}{|c|c|c|c|}
\hline & ḥina & lammā & baynā/baynamā \\
\hline Verbal form & fa'ala, yaf'alu & fáala & yaf'alu \\
\hline Position & subsequent & initial & initial \\
\hline Dependency status & embedded & mutually dependent & mutually dependent \\
\hline Semantic relation & $\begin{array}{l}\text { immediate adjacency } \\
\text { ('upon', 'when') }\end{array}$ & succession ('after') & inclusion ('while') \\
\hline
\end{tabular}

\section{$7 \cdot 5$ Summary}

In this chapter, I have discussed the semantic oppositions marked by the verbal forms in a selection of embedded clauses. I have tried to demonstrate how the interaction between the lexical content and the grammatical form defines the internal structure of the verbal situation and determines its relative time reference. Some aspectual and temporal properties of the verbal forms were observed in all types of embedded clauses. Other contextual features which were found to be pertinent across the board are: repetition and presupposition, deixis, specifically the distinction between particular and generic reference, and the epistemic position of the speaker/agent, which allows him to make more or less valid or confident predictions.

Special uses of the verbal forms were encountered in specific types of clauses. Thus, a consequential meaning of fa'ala and qad fa'ala was observed in asyndetic adjectival clauses whose antecedent is an internal object. In manclauses, fa'ala displayed what may be described as loose temporality, allowing for both anterior and non-anterior readings of the form. Moreover, some operators were found to have greater bearing on the interpretation of the verbal forms than others. Adverbial hina-clauses, for instance, express the meaning of 'sloppy simultaneity' with both fa'ala and yaf'alu, ${ }^{22}$ regardless of the nature

22 For the concept of 'sloppy simultaneity' see Declerck, When-clauses, 231, 244-248. 
of the verbal lexeme. The exclusion of qad facala from this type of clauses may also be attributed to the semantics of the operator hina. In contrast, the operators of substantival and adjectival clauses do not have such an effect on the temporal interpretation of the verbal forms. Rather, one may even discern in certain adjectival clauses the lack of temporal specificity or the preference of modal meanings over a strict temporal one. 